\title{
Analysis on social change among Bulghar society based on Risa- lah Ibn Fadlan 922 AD
}

\author{
Harliana Halim ${ }^{1}$, Kamaruzaman Yusoff ${ }^{2}$, Shakila Ahmad ${ }^{3}$, Mohd Faizal Abdul Khir ${ }^{4}$, Abdul Hafiz Abdullah ${ }^{5}$, \\ Shahidah Hamzah ${ }^{6}$, Hani Suraya Aziz ${ }^{7}$, Shamsaadal Sholeh Saad ${ }^{8}$, Mansoureh Ebrahimi' \\ ${ }^{I}$ Centre for General Studies and Co-curricular, Universiti Tun Hussein Onn Malaysia \\ ${ }^{2,5,9}$ Fakulti Tamadun Islam, Universiti Teknologi Malaysia \\ ${ }^{3,6,8}$ Centre for General Studies and Co-curricular, Universiti Tun Hussein Onn Malaysia \\ ${ }^{4}$ Faculty of Islamic Studies, Universiti Sultan Azlan Shah, Ipoh, Perak \\ ${ }^{7}$ Centre for Language Studies, Universiti Tun Hussein Onn Malaysia \\ *Corresponding author E-mail: harliana@uthm.edu.my
}

\begin{abstract}
The role of Islam in the forming of the society solidarity consisting of multi-ethnic backgrounds into a consistency ethno system is a great thing about the Volga Bulgaria that occupied by Bulghar society. The process of Islamization has become the main factors for social changes happened in the society. Thus, this writing is intended to analyse the social changes that occurred in the society that affected Bulghar society achievement, by referred to text analysis on Risalah Ibn Fadlan, 922 AD and some other sources related. For this study, the qualitative method using historical descriptive approach has been employed which involving compilation and evaluation of the facts of the Risalah Ibn Fadlān. Therefore, data onto this study were obtained through library research. The analyses on data study were conducted through texts and document analyses, as well as comparison method. This study finds islamization is the major factor contributing to the social change among Bulghar society. The social change in Bulghar society incorporating the changing of thinking to achieve development in education, the way of life, infrastructure, literature and the spirit of da ${ }^{c} w a h$, the norms and values based on Islam, which the society adheres after becoming Muslim.
\end{abstract}

Keywords: Bulghar Society; Social Change; Ibn Fadlan; Islamization

\section{Introduction}

Islam is the oldest religion among Bulghar entities who are residents along the banks of the Volga and Kama. The presence of Islam in this region has raised the name of Volga Bulgaria and this valley was once known as the first Islamic state founded in the Eastern Europe region. Volga Bulgaria's position strengthened after taking shelter under the cAbbāsiyah Islamic rule based in Baghdad. The note in some historical and historical geographical writings confirmed the existence of the Volga Bulgaria.

The role of Islam in shaping the unity of society comprising various ethnic backgrounds to a uniformity of the Volga Bulghar ethno system is a matter of interest in the Volga Bulgaria. The Islamization process of the Volga Bulgaria society has given their consciousness to emerge as a powerful Islamic power in Eastern Europe. Islam has also united Bulghar Muslim society with Finno Ugric pagan's society in a similar political society. The process of Islamization has become the main factors of social changes in the society. Thus, this writing is intended to analyse the social changes that occurred in the society that affected Bulghar society achievement, by referred to text analysis on Risalah Ibn Fadlan, $922 \mathrm{AD}$ and some other sources related.

\section{The Islamization of Bulghar society in his- tory}

The formation of the Volga Bulgaria state is closely related to the acceptance of Islam among a few Bulghar communities and the Bulghar government. It all started at the end of the eighth century AD. Trade links between the Volga regions have brought Sindj traders to a stopover in the Volga region on their way from India to Khurāsān, which located in northeastern Iran (1). The first stop of this group of traders in Volga Valley has pioneered trade relations to the early part in Bulghar. This trade relationship has also caused traders from the Arab Land to take this golden opportunity to trade in the Volga region, as well as spread the teachings of Islam in the region.

Beginning of this moment, the Volga Bulgaria people know Islam little by little as a result of their interaction with Muslim Arab traders. Furthermore, the acceptance of Islam by Aidar, the Bulghar government at that time became a spark of enthusiasm that spurred the Arab traders' efforts to spread Islam there. The contribution to pioneering trade routes and trade relations between the northern regions of Eurasia has led Sindh people to be the preferred option as a waypoint for traders Khurāsān who trade in the region.

In the meantime, in the early part of the tenth century, Aidar's eldest son, cAbd Allah was sent head of the Kara Bulgar embassy 
to the Khazar kingdom. However, the delegation was not allowed to return home and detained by the Khazar government. The Khazar government's action has caused cAbd Allah to decide on settling in Samandar. Samandar at that time was known as a settlement of the Khazar Muslim society that also functioned as a center of Islamic development in Khazar. Hence, the opportunity to be held in Khazar has been used by cAbd Allah to study Islam so that it is recognized as one of the scholars in Samandar.

In $817 \mathrm{AD}$, the majority of Samandar Muslims and the surrounding area rebelled against the Khazar kingdom. The rebellion is due to the attempts by the government to introduce Jewish religion to the people that have been receiving Islam for so long time. The Khazar Kingdom under the Khakan Karak regime that has embraced Judaism intends to make this religion the official religion of the country has forced its people to accept Jewish religion as their hold (2).

However, the Samandar rebellion has been defeated. He suspects ${ }^{c}$ Abd Allah who has been known as scholar as an agitator to the Samandar people's uprising and ordered him to be suspended from serving at Samandar Mosque. This incident caused cAbd Allah's eldest son, Mullah Shams flee to Kara Bulgar to meet Khan Aidar. Mullah Shams escaped to Kara Bulgar not only to hide himself but also to inform Khan Aidar of the possibility of Kara Bulgar being attacked by the Khazar in connection with the uprising in Samandar. Mullah Shams's concern lies in the fact that the Khazar rulers in the same year have attacked Kara Bulgar for thinking that Kara Bulgarlah was the mastermind of the rebellion. However, with the help and advice of the long-lived Mullah Shams in Khazar, Kara Bulgar has successfully overcoming the Khazar attack.

This Khazar attack was also an attracting factor for Khan Aidar to embrace Islam (3). Furthermore, the encouragement given by Mullah Shams reinforces Khan's desire to embrace Islam. Accordingly, after Khan Aidar's acceptance of Islam, a 'Djok' mosque in Kiev was erected to mark the acceptance of Islam among the leaders and members of the Kara Bulgar family on 203/819.

In 240-241 / 855, Kara Bulgar lost his first Islamic leader, Khan Aidar. The incident of Khan Aidar's death has shifted the power of the Kara Bulgar government to his son cAbd Allah Djilki who is a Muslim. However, the process of transition power of government to Djilki does not occur easily. Djilki has been opposed by his brother Lachyn who is still holding on with the ancient belief of Bulghar, Tengrism.

The difference in ideology between these two brothers has sparked more opposition between the two. Djilki has received the support of the Bulgarian Muslim society comprising the Baryn tribe of the Saban tribe. While Lachyn gets the continuous support from the Bulgar Tengrism society. The power struggle which initially was more of a civil war had changed into racial disputes between Muslim groups and the Tengrianis group. Furthermore, this racial dispute was further fueled by the presence of a third party Khakan Yskhak.

The great battle between Kara Bulgar and Khazar has taken place near the city of Baltavar. With the support of the BulgarTengrianis rebel group led by Lachyn, the Khakan Yskhak defeated the Djilki army. This defeat has affected the relationship between the two old Russian governments ie; first; Khakan Khazar has taken over the two areas of Kara Bulgar's shade of Kiev (Bashtu) and Novgorod (Urus) following the victory. These two areas were later combined by the Khazar government to form a new branch of the Khazar government territory known as 'Kievan Rus' or 'Old Russian State'. Khakan Yskhak has appointed a Norman with the title Dir as the first ruler of Kievan Rus. The Kievan Rus region covers the area on the right bank, the middle of the Dnieper River.

The effects of both strings of the Djilki and Khazar battle were Khan Djilki who had been banned from entering Karadjar's town and dismissed from ruling the territory. Karadjar was then placed under the responsibility the new Chernigov provincial government. Meanwhile, the kingdom of Kara Bulgar is still allowed to rule the colonies located in the southern part of the Dnieper as well as the northern part of the Crimean Peninsular. However, Kara Bulgar was no longer ruled by Djilki but was handed over to Lachyn as a new government as his support and assistance to the Khazar government. Under the new government, the town of Khorysand has been the center of political rule for the kingdom of Kara Bulgar. The latest directive of the Khazar government has led to the split of Kara Bulgar Empire into three small states. The states involved were Rus, the kingdom of Kara Bulgar and the Karadjar region. These three territories are governed by three military forces namely the Bulghar-Tengrianis, the Norman mercenaries and the Slavs who are based in Kiev and Novgorod. These three parties received Khazar's support from military and political aspects. This is a threat to Djilki who has lost power of government. However, he still has strong support from Bulghar Muslims.

In 248-24 / 863, Djilki has attempted to reunite the split Kara Bulgar Empire. He took action against the city of Baltavar suddenly. Kara Bulgar at that time was still ruled by Lachyn. This sudden attack caused Lachyn to leave Baltavar and retreat to Khazar for protection. Djilki's army captured Baltavar and continued their mission to capture Kiev. The city could easily be captured when the son of Dir surrendered himself and expressed his loyalty to the Djilki as a ruler.

With the victory, Djilki returned to his home at Baltavar and declared himself a legitimate Kara Bulgar government. Although the Kara Bulgar government was successfully consolidated, however, the following year, Khakan Khazar had attacked Djilki with a force of 75,000 men and forced Djilki to take refuge in Karadjar's fortress again.

When Khan Djilki ruled Kara Bulgar, he had received news from a trader named Tuymaz in connection with the absence of replacement Bulgarian government in Middle Volga region after the death of his leader, Prince Barys (1). Some of the Bulghar people agreed to invite the son of the Khazar Empire to replace Prince Barys to rule the region again. Hearing this news, Khan Djilki has acted to direct his prince, Almas led a 10,000 strong troop army to the West Bulgaria region while he himself moved to the KamaVolga region. Upon arriving in Bulgar, he was blocked by residents from entering the city. However, with the aid received from Kuman tribes and the support of the Bulgarian society in Bulgar, Djilki successfully conquered the city and declared him Bulghar government in the Central Volga region and declared the small Bulgarian as an Islamic state in 251/865. In connection with the declaration, Bulgaria began to be known as Volga Bulgaria by Muslim writers. In conjunction with the event, the Bulghar society continued under the rule of Islam until the year 310/922.

The throne of the Bulghar government in Volga is now led by a Muslim with the support of the Bulghar Muslims. Djilki, having succeeded in mastering the throne of Bulghar's government, has begun a desire to make Bulghar in Volga a free state. This would raise the status of the country compared to the status of colonies as in Kara Bulgar bound with the power and government of Khazar. Hence, the path he sees that will help him to achieve his goals is to establish a relationship between Volga Bulgaria and Baghdad. Baghdad is seen as a capable force to help Volga Bulgaria to stand as an independent state.

\section{Social change among Bulghar society based on Risalah by Ibn Fadlan}

Risalah Ibn Fadlan also contains notes about the social changes that the Bulghar society had endured after their conversion. From the social aspect, Bulghar's society of Islam has contributed to the formation of Volga Bulgaria and the Baghdad relations under the Caliph al-Mu'tadid, which is among the leaders of the Abbasid Caliphate. This relationship is reinforced by the decree of Baghdad delegation on 309/922 which has led to the participation in the Bulghar society to become part of the Muslim ummah under the rule of the Islamic empire centered in Baghdad (4). In the same year, Islam was declared the official religion of the Volga region of Bulgaria $(5,6)$. Prior to the arrival of the Baghdad delegation, 
Islam has been the holding of most of its inhabitants who inhabit the volcanic and volcanic cliffs.

Thus, the arrival of the Baghdad delegation decided by the Caliph al-Muqtadir, apart from fulfilling three Almas demands, also aims to meet five thousand Muslims who have embraced Islam before. The Volga Bulgaria group known as al-Barandjar is among the earliest Muslims in the Volga and Kama Valley. Their existence has been identified from the note of Ibn Rustah, an Arab traveler who wrote most of the Volga Bulgaria population in the Middle Volga Valley is comprised of Muslims. In fact, they are also said to have own mosques and religious institutions.

With regard to the prevailing intellectual development in Baghdad, Volga Bulgaria does not face the same problem. Possible location factors have prevented Volga Bulgaria from facing internal problems as happened in Baghdad despite Volga Bulgaria sheltering under Baghdad. Furthermore, the people of Volga Bulgaria firmly adhere to the practice of the Hanafi sect as a result of the preaching efforts of the Central Asian traders. Therefore, the social change of the society in terms of the practice of Islam in the context of the exchange of the Volga Bulgaria Muslim sect is well done, without any serious problems.

On the other hand, Ibn Fadlan's note shows Baghdad's delegation has focused on the efforts of the spread of Islam and the appreciation and understanding of the Volga Bulgaria society on Islamic doctrines as the fundamental principles (7). Although religious teachers, as termed Bukharaev, were in the early stages of reluctance to continue to Volga Bulgaria due to the financial difficulties faced by the delegation, but that did not prevent the Islamic pamphlet that led to social change in society. This is because the role has been taken over by the rest of the existing entourage especially Ibn Fadlan.

Such failure also does not prevent social change from the aspect of implementing Islamic law as desired by Volga Bulgaria government. The Volga Bulgarian Islamic region has also implemented the Islamic administrative and legal system with the help of members of the delegation. The role played by delegate members, though only about four, has helped Bulghar leaders transform Volga Bulgaria to the true Islamic foundation. Ibn Fadlān's notes regarding his role and other members of the Baghdad delegation in teaching the Volga Bulgaria people on the question about Islam clearly proved that the expected social goals had been achieved (7).

The Bulghar society had abandoned the jahiliyyah way of life that had been practiced in the past. Now they practice a true Islamic way of life. This religious consciousness has also led to the awareness of the importance of knowledge as the foundation of the construction of the civilization of the ummah. The Muslim Bulghar society was also being introduced the Arabic scripts. The introduction of the script is not only a proof of the spread of Islam, but also a factor in the development of Islamic culture and knowledge.

It is worth mentioning here that Bulghar land does not have any civilization in terms of writing until they embrace Islam. Although the Volga Bulgaria had previously used the Orkhon Turkish alphabet in writing, the alphabet was not regarded as the absolute alphabet of Bulghar. The actual writing system has been developed and evolved in tandem with Bulghar's economic development after formal acceptance of Islam, where all matters involving tax, legislation and politics are recorded. Records were written on the wood and plaque made from sand until the fourth century when paper produced by the Islamic empire was brought from Khwarizm city in Central Asia to Volga region. With the acceptance of Islam by the Bulghar society, the Arabic script began to replace the Bulghar alphabet. Two types of Arabic calligraphy, Kūfi and Thūlus, are among the most popular types of calendars in the Bulghar society (8).

Bulghar's alterations to the Arabic script have contributed to the new development of Bulghar literature in the 12th century. The existence of literary language has also affected the education system and the development of educational awareness among the Volga Bulgaria society. The Volga society of Bulgaria began to realize the importance of education as a platform for the advancement of the nation. The Volga Society of Bulgaria began to realize This development is in line with the growth of educational institutions such as madrasah which not only focused on religious education a core but also introduced other fields of knowledge to strengthen the mastery of knowledge and skills. The existence of a mosque building of wood, as well as religious centers known as 'maktab', has reinforced the evidence that Islam has indeed established itself in the area. For example, by the end of the third century, there were 42 religious studies colleges in Volga Bulgaria.

The development of the Volga Bulgaria education system is in line with the education efforts in Baghdad that not only emphasize on religious aspects but also emphasize on the development of other sciences. Additionally, the Volga society began to look at educational institutions as an important institution that played a leading role in producing future scholars and country bureaucrats. The existence of this institution will be able to eradicate illiteracy among the Bulghar society.

Religious awareness has become the major factor on awareness of the importance of educational institutions to produce Bulghar scholars. Bulghar scholars in the twelve and thirteen centuries have earned recognition among local and foreign communities. Bulghar's historian, Yackūb ibn Nucmān, who wrote about the history of Bulgarya in $1112 \mathrm{AD}$, is among the valuable records of the history of the society. Ibn Nucman was not the only Bulghar scientist born in the region. In addition to him, there are other scholars such as Burhān ad-Dīn Ibrāhim ibn Yūsuf with his writing in the field of rhetoric, medicine and religious commentary. In addition, some other names such as Hamīd ibn Idrīs, Ahmad alBulghāri, Muhammad Sadr ibn cAla ad-Dīn, Hassan ibn cUmar and Muhammad al-Bulghāri are among Bulghar scientists born of the development of educational institutions in Volga Bulgaria (9). Unfortunately, history only records the name of one Bulghar poet Kul Gāli while the rest is setting aside. Kul Gāli's poem entitled "Qissaiy Yusuf" has attracted literary and linguistic historians to study it as this poem illustrates the spiritual glory that Bulghar people have achieved before the 7/13 century as a result of their acceptance of Islam in the previous century. The aspirations of Islam have indirectly affected the souls of the Volga Bulgaria. The success and excellence of Islamic civilization at that time has injected the spirit of the Volga Bulgaria people to succeed as has been achieved by the previous Muslims

In addition, the population of the Volga Bulgaria consisting of five main clans namely the Bulghar, Suwar (Savan), Esegel (Askel), Serpent and Barandjar tribes showed a diversity of factions united under one Islamic rule. Although the Central Volga valley is inhabited by various tribes, it seems that only one form of culture is left to the effect. This is evidenced by the discovery of the same patterned pottery in the 1960s in the area along the upstream of the Sura River, the Mokhsa River and the Vada River.

The diversity of clans under one Islamic rule proves that Islam has brought unity to Volga Bulgaria. Islamic unity in Volga Bulgaria has been a major factor in the formation of a nation. This is another positive social change experienced by the Bulghar society. Of course the idea of this unity is emulated from Baghdad comprising various tribes and descendants also united under th rule of the Abbasid Islamic empire according to Harliana Halim's study, 2013. In this regard, the main model is the head of the Prophet s.a.w. in the formation of the Islamic state of Medina.

Eight years after the Baghdad delegation left Volga Bulgaria, a city and a mosque stood up proving that Amīr Bulghar ruled Volga Bulgaria on behalf of the Khalifah and held on to Islam. Although the acceptance of Islam at the beginning of the Bulgarian government was merely a 'leader of determining religion' in accordance with Islamic proponents, but subsequent social change developments exhibited the lush Muslim culture among the Bulghar society without compulsion.

The firmness of the Bulghar society towards Islamic teachings can be seen with the growth of mosques in every major city of Volga Bulgaria as a place to perform Friday prayers. Moreover, Hudud al- ${ }^{\mathrm{C}}$ Alam reinforces the fact that Bulghar and Suwar people are 
actively fighting to spread Islam. According to al-Mascudi, one of the Bulghar government's children had performed the pilgrimage in Mecca during the reign of Khalifah al-Muqtadir. Other evidence showing the emphasis of the Volga Bulgaria government against Islam is the existence of the Sabzawar and Khusrawdjird mosques built in 415/1024 by Amīr Bulghar Abū Ishāq bin Ibrāhim bin Muhammad. This suggests that social change caused by Islamism had a positive effect on the Bulghar society.

At the same time, the spirit of spreading Islamic propaganda was also inherited. Bulghar preachers tried to appeal to other Bulghar people, such as the Pecheneg and Germs, to Islam and hope to spread Islam throughout Russia still in bondage with the pagan beliefs. For example, in 375/986, a delegation of the Volga Bulgaria religious delegation was sent to Kiev to meet with Prince Vladimir to summon him to convert to Islam. Although the delegation failed to attract Prince Vladimir to embrace Islam, the efforts undertaken had proved the seriousness of the Muslim society of Bulghar to convey Islam throughout Europe.

\section{Conclusion}

Islam has led to a social change on Bulghar's society in line with the spirit of Islam that calls to the progress and success. Under the Islamic government, the Middle Volga Valley developed into an Islamic state with the new name, Volga Bulgaria as it has been recorded in historical writings at that time. The acceptance of Islam by the Bulghar society officially became a momentum for the outstanding achievements of Volga Bulgaria later, whether from political, economic or social aspects, despite the threat of the Mongol empire under the leadership of Ginghiz Khan in the thirteen $\mathrm{AD}$.

\section{Acknowledgement}

This research is funded by the Ministry of Higher Education through, Research Acculturation Collaborative Effort Grant (RACE), Vot 1516 Universiti Tun Hussein Onn Malaysia. Special thanks you to RACE Grant Secretariat, Ministry of Higher Education Malaysia, Research Management Centre UTHM, Centre for General Studies and Co-curricular (PPUK), Universiti Tun Hussein Onn Malaysia, Faculty of Islamic Civilization (FTI) and RMC Universiti Teknologi Malaysia.

\section{References}

[1] Mifthakov. The First Islamic State In The Itil Basin. Lecture Course History of Tatar People. 2002.

[2] Golden M, Birns B. Social class and infant intelligence. Origins of intelligence: Springer; 1983. p. 347-98.

[3] Bukharaev R. Islam in Russia: TheFourr Seasons. New York: St Martins. 2000.

[4] Halim H, Yusoff K, Ghazalli AJ. Relations between volga bulgaria and baghdad. International Business Management. 2013;7(1):21-30.

[5] Faḍlān AI. Ibn Fadlan and the land of Darkness: Arab travellers in the Far North: Penguin UK; 2012.

[6] Bukharaev R. The BBC and Poetry. Wasafiri. 2011;26(4):53-4.

[7] Halim H, Yusoff K, Khir MF, Ahmad S. Analisis kebangkitan Volga Bulgaria 922 M. 2015.

[8] Bianquis T, Bosworth C, Donzel Ev, Heinrichs W. Encyclopaedia of Islam CD-ROM Edition v. 1.0. Leiden, The Netherlands: Koninklijke Brill NV. 1999.

[9] Bukharaev R. Islam in Russia: the four seasons: Routledge; 2014. 